\title{
The CERESIS earthquake catalogue and database of the Andean Region: background, characteristics and examples of use
}

\author{
Alberto Giesecke $\left({ }^{1}\right)$, Augusto Antonio Gómez Capera $\left({ }^{2}\right)$, Ilaria Leschiutta $\left({ }^{2}\right)$, \\ Elena Migliorini $\left({ }^{2}\right)$ and Leandro Rodriguez Valverde $\left({ }^{1}\right)$ \\ (1) Centro Regional de Sismologia para América del Sur (CERESIS), Lima, Peru \\ ${ }^{(2)}$ Istituto Nazionale di Geofisica e Vulcanologia, Sezione di Milano, Italy
}

\begin{abstract}
The history of earthquakes in South America starts with the coming of the Spanish and Portuguese «conquistadores» at the beginning of the 16th century. Their chronicles, and those of local historians, are the only source of earthquake information for the following 400 years. The creation of the Regional Centre for Seismology for South America (CERESIS) was a major factor for homogenous regional progress, in that CERESIs promoted the implementation of the first unified earthquake catalogue and database for the whole Andean Region. This paper reviews basic information about the intensity database and the focal parameter catalogues proposed by CERESIS in 1985. Further macroseismic data available from the CERESIS database (earthquakes with $I_{0} \geq$ 8) are used to obtain preliminary results for the earthquake source parameters of selected South American historical events. The case of the Great Earthquake of the Venezuelan Andes, 29 April 1894, is presented in some detail.
\end{abstract}

Key words historical seismicity - South America CERESIS database - intensity data points - earthquake source parameters

\section{Introduction}

The Andean chain is the result of subduction of the Nazca Plate beneath the South American Plate, which extends for more than $9000 \mathrm{~km}$ along the western margin of South America. The activity associated with plate boundaries defines a zone of convergent tectonics, which causes ac-

Mailing address: Dr. Alberto Giesecke, Centro Regional de Sismología para América del Sur (CERESIS), P.O. Box 14-0363, Lima, Peru; e-mail: giescere@inictel.gob.pe tive internal deformation in the Andean block, as evidenced by neotectonic activity and a concentration of seismicity along the inter-Andean valleys and coastal fault systems. The Andean region is one of the most active seismic regions of the world and it accounts for about $15 \%$ to $20 \%$ of the total seismic energy released by planet Earth. Several great earthquakes hit the Andean countries of South America (Argentina, Bolivia, Chile, Colombia, Ecuador, Peru and Venezuela) in the past centuries.

It was generally recognised, half a century ago, that in many parts of the world progress in seismology depended on the degree of organised regional co-operation. For this reason, UNESCO supported the creation of regional centres. A UnESCO Mission, led by Prof. V. V. Beloussov, visited Latin America in the early 
1960s to explore the possibility of establishing a seismological centre for South America. The Mission recommended that such a centre be located in Lima, Peru. In 1966, UNESCO and the Government of Peru signed a Bilateral Agreement to create the centre; UNESCO provided operating funds for a five-year trial period and for a full-time director; Peru provided the local facilities. A Board of Directors (seismologists, geophysicists, earthquake engineers) was appointed by the government of each participating country (including Trinidad and Tobago), and a representative of the Division of Earth Sciences of UNESCO and of PAIGH (Commission of Geophysics of the Pan American Institute of Geography and History) formulated policy, planned and supervised the centre's activities.

UNESCO's financial support ended in 1971. A meeting of high level government representatives of the CERESIS (Regional Centre for Seismology for South America) countries was held in Lima. They decided to convert CERESIS into a permanent, official and autonomous international organisation for the South American region, belonging to the governments of its member states. A multinational agreement was drafted and signed by five countries (Bolivia, Colombia, Peru, Uruguay and Venezuela) and went into effect on 1st July 1971; the document was deposited at the Ministry of Foreign Relations of Peru and it remains open to adhesion of other countries that wish to become member states. Argentina, Trinidad and Tobago, Ecuador, Chile, Spain, Brazil and Paraguay have also signed the agreement, and most of them have subsequently ratified it.

The goal of CERESIS is to improve the knowledge of seismology and related disciplines and to apply such knowledge to improve the region's capacity to cope with earthquake and volcanic hazard. Since its beginning, CERESIS recognised that a unified catalogue of earthquake parameters for South America was essential for progress in many areas of seismological research such as regional studies of seismicity, seismotectonic and the evaluation of seismic hazard. The decision was thus made to produce a regional catalogue. This was made within the SISRA Project (Earthquake Mitigation Program in the Andean Region Project) in
1985, which focused on the determination of hypocentral parameters for South American earthquakes. For the pre-instrumental period and/or poorly monitored areas, intensity values, and focal parameters when possible, were determined by investigating and interpreting historical reports and chronicles.

In the nineties, in many of the CERESIS countries, there was a loss of interest in integrating national catalogues, and intensity data above all, for regional purposes. Fortunately, present generations of seismologists and earthquake engineers recognise the importance of upgrading intensity data and keeping the regional catalogue up to date. Despite the fact that «intensity» is not a scale which is based on instrumental measurements, it is nonetheless designed to quantify damage caused by earthquakes, an aspect which no other instrumental parameter can measure as satisfactorily. Practical applications of intensities are illustrated by the following examples:

i) Earthquakes are the largest financial risk faced by insurance companies. Therefore, these companies must be as highly informed as possible about the risks they might encounter. For example, the well-known Skandia Group Insurance Co. uses the CERESIS «Maximum Intensity Map of South America» as a tool to evaluate risk in the Andean region.

ii) In Chile, «quality of soil» maps have been prepared as a function of differences of Modified Mercalli Intensity (MMI), observed between different types of soil during the same earthquake. Accurate estimates of the possible intensity at a given location have been achieved as a function of magnitude and distance, on the basis of attenuation equations relating magnitude-distance-intensity. Such expressions have the virtue of being very reliable due to the fairly large quantity of data available over a very broad range of intensities, distances and magnitudes.

CERESIS has presented a proposal to the Commission of Geophysics of the Pan American Institute of Geography and History (PAIGH) to interpret and catalogue the large amount of intensity data (mostly in MM, Modified Mercalli scale) accumulated in South America over the past 20 years. We hope this effort will lead to a CERESIS training project, with the participation of historians and seismologists, to produce 
in each country a group of professionals, with the required expertise, training and capacity, who are essential for reliable and consistent assessment of intensity.

\section{Background of the Andean Region catalogue and intensity database}

Historical earthquakes in South American countries are found in historical documents from Spanish colonial times, ancient newspapers, personal notes, chronicles, records of public offices, etc. These were mainly compiled by ecclesiastical authorities, and governors. Early compilations of earthquakes were produced by some scientists and scholars. Such compilations, including, for instance, Boussingault and Roulin (1849) in Ecuador, and Montessus de Ballore (1912, 1916) in Bolivia and Chile, can be considered the first seismic catalogues of South America.

During the past century, Jesuit seismologists gave an outstanding contribution to the development of modern seismology in South America. Fathers Pierre Descotes, Luis Fernández and Ramon Cabré in Bolivia, German Saa in Chile and Peru, Rafael Goberna in Cuba and Colombia, Jesus Emilio Ramirez in Colombia, were part of a generation of Jesuits who played an important role in studying earthquakes in different parts of the world.

Historical research was proposed by SISRA Project and supported by the US Geological Survey, financed by the US Office of Foreign Disaster Assistance and the CERESIS countries. Historical compilations of destructive earthquakes of South America from 1530 to 1894 are published in vol. 10 of CERESIS (1985), which contains information collected by Silgado $(1978,1985)$ in several public and university libraries, local and central government offices and archives in South America, Spain, France and England. Data from the Spanish colony were found in Spain at the Archivo General de las Indias in Sevilla, at the Biblioteca Nacional de Madrid, at the Archivo Histórico Nacional and at the Real Academia de Historia. In London, Silgado found data about earthquakes from colonial and republican time of South America at the British Li- brary, «Sección de Manuscritos Españoles». He also consulted reports of the English consuls of the 19th century, stored in the Public Record Office at Kew, U.K. In France, Silgado searched at the Bibliothèque Nationale de France in Paris, where he consulted the «Catalogo de los manuscritos españoles de Alfred Morel Fatio» and the manuscripts of Montessus de Ballore, which are a compilation of South American earthquakes from colonial time to the end of the 19th century. In Strasbourg, Silgado consulted Perrey's works at the library of the Institut de Physique $d u$ Globe. Finally, Silgado (1985, 1992) derived intensities of historical earthquakes of South America by interpreting the historical descriptive texts.

The intensity scales most commonly used in South America are the Modified Mercalli scale (MM) and the Medvedev-Sponheuer-Karnik scale (MSK). However, there is growing interest in the new European Macroseismic Scale 1998: EMS (Grünthal, 1998), which derives from the necessity to introduce in the MSK scale both new types of buildings (engineered and antiseismic construction) and the criteria of vulnerability. At best, intensity assessment is a complex endeavour that requires expertise, professional skill and remarkable historical background. Therefore, it is better evaluated when historians and seismologists work together.

National maps of maximum intensities (MM macroseismic scale) at a scale of 1:2000000 were adjusted and integrated to produce a regional map of South America at the scale 1:5000 000 (CERESIS, 1985). Isoseismal maps of 220 strong earthquakes and values of intensity at selected locations were integrated. Juan Carlos Castano, Director of INPRES (Instituto Nacional de Prevención Sísmica), Argentina, was the regional co-ordinator for the map.

CERESIS provided an unparalleled framework aimed at unifying and upgrading the various existing national catalogues and intensity data (fig. 1a,b). The most important work on the CERESIS hypocentre catalogue was done by the national groups of each participating country, who entered the data using common formats agreed by the national representatives. The regional co-ordinator for the catalogue was 

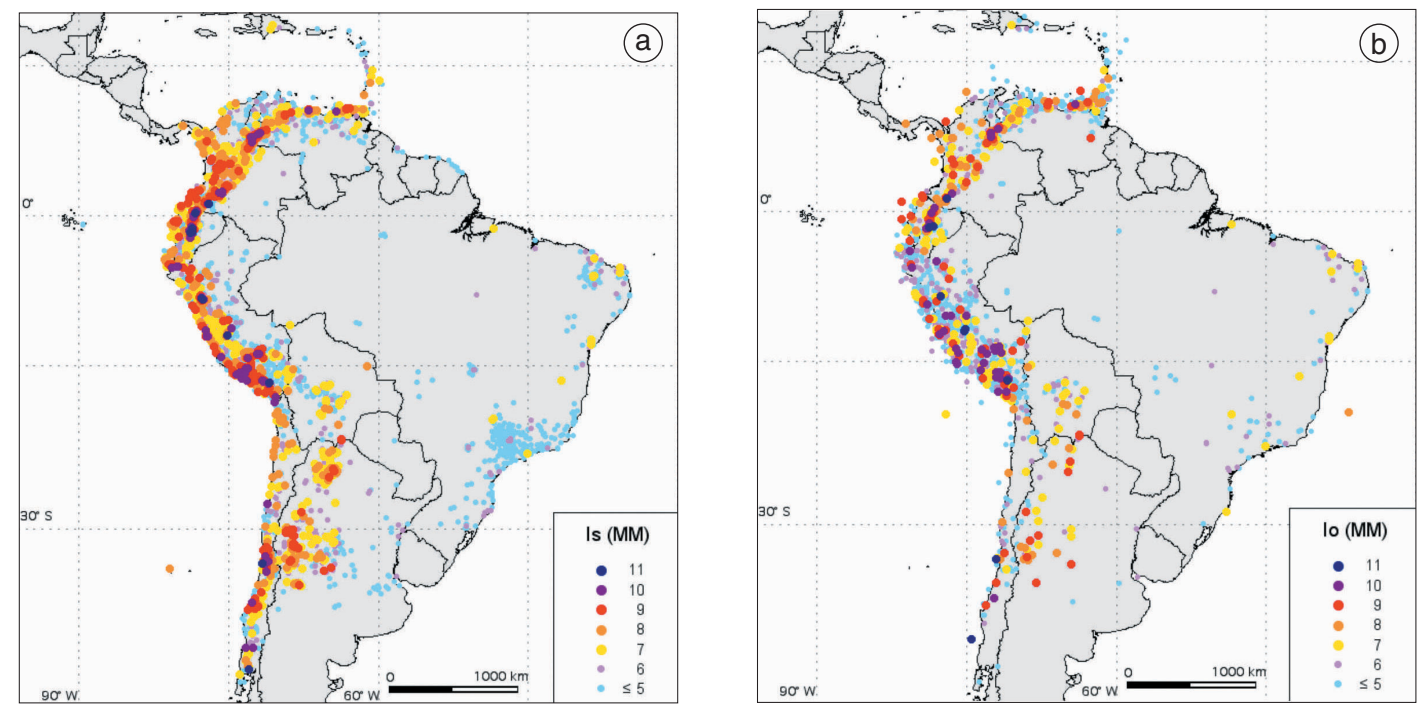

Fig. 1a,b. a) IDP distribution from the CERESIS database; b) Epicentre distribution from the CERESIS database.

Leonidas Ocola of the Geophysical Institute of Peru. The regional catalogue, edited by Askew and Algermissen (CERESIS, 1985), covers a time period which begins with the earliest known historical event (1471) and ends in 1985.

Below, we briefly describe the state-ofthe-art of historical seismology studies for Ecuador, Peru, Bolivia, Chile, Argentina, Brazil, Paraguay and Uruguay. The situation for Colombia, Venezuela, and Trinidad and Tobago is described in Espinosa et al. (2004), Altez and Grases (2004) and Vogt (2004).

\subsection{Ecuador}

The Observatorio Astronómico de Quito (1959) compiled a descriptive and parametric catalogue of earthquakes that occurred between 1534 and 1958 as a contribution to the International Geophysical Year. The catalogue and intensity database compiled in the framework of the SISRA Project and published in vol. 6 of CERESIS (1985), are based on information from Observatorio Astronómico de Quito (1959), Egred (1968) and data from international seis- mological agencies. Historical archives were consulted as the Archivo Municipal de Quito, the Archivo Nacional de Historia, the National Library and the Aurelio Espinosa Polit Library in Quito. Historical sources are quoted as for example «Libros de Cabildo de la Ciudad de Quito» (1645, 1675, 1775), documents from Spanish colonial times.

At present there is interest amongst historians in Ecuador to investigate the social, economic and political impact of major earthquakes and volcanic eruptions.

Special care was taken to interpret the language and avoid confusion between earthquakes and volcanic eruptions, to attenuate the tendency to exaggerate or ignore evidence according to personal criteria. Both descriptions of large events by different authors and documents found in Sevilla (Archivo General de las Indias) and in the archives of the convents within Ecuador have been compared. Another difficulty was that caused by place names, since some localities have changed their names over the years. For some of them it has been impossible to find a reliable location. 


\subsection{Peru}

Primary historical sources in Peru span from the Spanish Conquest (16th century) and Spanish colonial times to the 19th century. These sources are anonymous notes, letters, chronicles, records of public offices prepared by ecclesiastical authorities, governors, etc. Polo (1904), Barriga (1951) and Silgado (1968) investigated both Peruvian libraries and archives and the Archivo General de las Indias in Sevilla. The results of this research were used for the catalogue of strong earthquakes (Espejo, 1974) compiled by the Instituto Geofísico del Perú and for the Peruvian parametric catalogue (Ocola, 1984) prepared in the framework of the SISAN Project (Sismicidad Andina, Andean Seismicity). At the same time, Huaco (1983) performed historical investigations and quantification of historical information and similar studies were published by Silgado $(1978,1985)$. The results obtained by this second wave of research are at the basis of the Peruvian catalogue and intensity database published in vol. 7 of CERESIS (1985).

Further studies (e.g., Dorbath et al., 1990; Silgado, 1992) made possible a revised and updated Peruvian CERESIS catalogue from 1470 to 1982 , which is available since 2000 at http://www.igp.gob.pe/

\subsection{Bolivia}

The Jesuit priest Pierre M. Descotes (18771964 ) is considered the father of seismology of Bolivia. For more than 50 years, he served as Director of the San Calixto Observatory (OSC). Father Descotes collected and studied all available references for historical earthquakes (Descotes and Cabre, 1973), particularly Ballivian (1909) and Montessus de Ballore (1912). Vega (1978) compiled a first systematisation of seismological information through the project SISAN where the main bibliographical sources were Descotes's work and publications from the international seismological agencies. The CERESIS catalogue and intensity database for Bolivia was compiled on the basis of the SISAN catalogue (Vega, 1978) and a search of more data in his- torical archives as the Archivo de Potosi and the Archivo Nacional de Bolivia. Some historical sources and ancient newspapers are quoted by CERESIS (1985), as for example: Anonimous (1650), Lara (1860), La Industria (1884, newspaper of Sucre town) and La Estrella de Oriente (1890, newspaper of Santa Cruz town). This catalogue, critically revised and complemented, was published in vol. 3 of CERESIS (1985). The compilation of the catalogue continued up to the 1981, using data of both the U.S. Geological Survey and the International Seismological Centre (ISC).

\subsection{Chile}

The catalogue of earthquakes for Chile covers a long history. The compilation of events that occurred in colonial times were in general related to studies aimed at compiling texts on the history and geography of Chile, rather than for scientific purposes. Montessus de Ballore (1911, 1912 , 1916) produced the most complete catalogue of historical Chilean earthquakes. Greve (1964) and Lomnitz (1970) have added historical information to this catalogue. During the first four decades of the 20th century several international institutions and universities began the preparation of world catalogues with valuable information related to Chile. The Department of Geology and Geophysics of the Universidad de Chile, Santiago, runs the Chilean Seismological Service. A catalogue of destructive earthquakes is available at http://ssn.dgf.uchile.cl/home/ sismohisto.html/

The Chilean catalogue and database compiled by SISRA Project, and published in vol. 5 of CERESIS (1985), are documented in detail mainly by Greve (1964), Lomnitz (1970), Kausel (1979a, 1979b).

Some problems were nonetheless encountered in the compilation of intensity database for Chile. For example, some localities related to the 1868 and 1877 earthquakes do not have co-ordinates and their names are not known, possibly because they correspond to places in southern Peru, western Bolivia or Chile, which either were abandoned or changed their names. 


\subsection{Argentina}

A working group at INPRES (Instituto $\mathrm{Na}$ cional de Prevención Sísmica) was appointed to prepare the national catalogue of Argentina in early 1980's. Their first step was to compile all available data, historical and instrumental, pertinent to earthquakes that affected the Argentine territory. When the SISRA Project started, what was previously achieved was reviewed in order to proceed within the guidelines and formats proposed by SISRA. New information on destructive earthquakes was obtained from different historical sources, mainly newspapers and magazines of the time for different places in the country. Thus, the first Argentine catalogue and intensity database was compiled (CERESIS, 1985). This catalogue quotes studies and compilations from Lunkenheimer (1930), Olsacher (1935), Harrington (1944), and Volponi (1962). A parametric and descriptive catalogue is today available at http://www.inpres.gov.ar/

\subsection{Brazil, Uruguay and Paraguay}

Although seismic hazard in Brazil, Uruguay and Paraguay is low, it is worth stressing that these three countries voluntarily joined and support CERESIS. Since they occupy most of the Precambrian shields of the continent and are located in the internal continental region of the South American Plate, seismic activity is expected to be low, similar to other intraplate regions on the earth.

The first seismological station in Brazil was established in 1921 in Rio de Janeiro. The present national network includes several local and regional sub-networks and many first order stations. The study of the seismicity of the Brazilian territory has intensified in recent years. This is explained by i) the interest of Brazilian seismologists, CERESIS and the University of Edinburgh in the installation of the South American (Seismic) Array System, near Brasilia, ii) the necessity of carrying out detailed studies on seismicity and seismic risk for the construction of large hydroelectric dams and nuclear reactors, and iii) the rather constant occurrence of small and, generally, non-destructive earthquakes of intensity V MM. Seismic activity is observed on the continent near the Atlantic coastline, from Belem in the north to St. Catarina, south of Sao Paulo. Induced earthquakes of magnitude $m_{b} 3.5$ to 3.7 have occurred twice in Parana. The important contribution Brazil gave to South American seismology was to improve the locations of several Andean epicentres.

A working group of seismologists from the Instituto Astronómico e Geofisico, the Instituto de Geociencias (USP) and the Estação Sismológica de Brasília, at the request of the National Commission for Nuclear Energy, undertook a study of the seismicity of Brazil. The resulting catalogue was published by Berrocal et al. (1984) and includes historical events dating back to 1560 . Previous attempts to compile a catalogue began with Capanema (1859).

In Uruguay, the Universidad de la República in Montevideo is the liaison institution with CERESIS. Uruguay's interest in seismology is related to large engineering projects, e.g., the Salto Grande dam (a bilateral project with Argentina) and the $60 \mathrm{~km}$ long bridge across the La Plata river, from Buenos Aires to Colonia. The CERESIS regional seismicity map shows one seismic event located in the middle of the La Plata, close to where the bridge will probably be built. The maximum intensity map shows that the area has an intensity of V MM.

In Paraguay, the Universidad Nacional de Asunción (Facultad de Ciencias Exactas y Naturales) is the national liaison institution with CERESIS. Paraguay operates one of South America's four GTSN, high gain, stations located about $100 \mathrm{~km}$ south of Asunción. Three other GTSN stations are located near La Paz, in Bariloche (Argentina) and in Brasilia.

\section{Characteristics of the CERESIS database and use}

Macroseismic data are frequently used for parameterisation of the seismogenic sources and evaluation of seismic hazard. Consequently, several seismological institutions have formalised their historical data into homogeneous macroseismic databases and have developed 
online databases to increase the dissemination of data through the web (see Rubbia, 2004).

The CERESIS database (http://www.ceresis. org) is the main source of Intensity Data Points (IDP) for South America, it contains 16318 IDP (fig. 1a) related to 3183 events (fig. 1b) that occurred from 1471 to 1985 in eight South American countries and one Caribbean country (table I).

The format of the CERESIS database includes two types of record as shown in table II. For each event, the first line provides the earth-

Table I. Time-windows, number of earthquakes and related IDP in the CERESIS database.

\begin{tabular}{lccc}
\hline \hline Country & Time - window & No. of earthquake & No. of IDP \\
\hline Argentina & $1692-1985$ & 45 & 703 \\
Bolivia & $1650-1981$ & 45 & 208 \\
Brazil & $1767-1981$ & 114 & 431 \\
Chile & $1730-1977$ & 61 & 816 \\
Colombia & $1566-1981$ & 188 & 2097 \\
Ecuador & $1541-1980$ & 153 & 1416 \\
Peru & $1471-1981$ & 2023 & 8354 \\
Trinidad and Tobago & $1825-1981$ & 23 & 78 \\
Venezuela & $1530-1981$ & 531 & 2215
\end{tabular}

Table II. Example of CERESIS database format. Examples of duplicate record, as for different «interpreter» (i.e. Callao: DH or UTLO) or uncertainties in the intensity assignment (i.e. Callao $I=8 / 9$ ), are reported.

\begin{tabular}{|c|c|c|c|c|c|c|c|c|c|c|c|c|c|c|c|c|}
\hline $\mathrm{Cou}$ & Code & $\mathrm{Ye}$ & $\mathrm{Da}$ & $\mathrm{Da}$ & Ho Mi Se & $I_{\text {Lat }}$ & $I_{\text {Lon }}$ & $M_{\text {Lat }}$ & $M_{\text {Lon }}$ & \multicolumn{2}{|c|}{$D_{p h}$} & $M_{s}$ & $I_{0}$ & & & $N_{e}$ \\
\hline HYP & PE 120 & 1586 & 07 & 10 & 00:30:00 & & & -12.300 & -77.700 & \multicolumn{2}{|c|}{60} & \multicolumn{4}{|c|}{$10 \mathrm{M}$} & 12 \\
\hline PE & LIMA & & & & & & & -12.10 & -77.00 & 100 & 76 & & 81 & $8 \mathrm{~K}$ & DH & 421 \\
\hline$P E$ & CALLAO & & & & & & & -12.05 & -77.15 & 32 & 62 & & 74 & $8 K$ & $D H$ & 421 \\
\hline$P E$ & CALLAO & & & & & & & -12.04 & -77.09 & 20 & 10 & 41 & 319 & $8 K$ & UTLO & 411 \\
\hline$P E$ & $C A L L A O$ & & & & & & & -12.04 & -77.09 & 20 & 10 & 41 & 319 & $9 K$ & UTLO & 411 \\
\hline PE & CARAVEL & & & & & & & -15.77 & -73.36 & 1779 & 567 & 568 & 136 & $3 \mathrm{~K}$ & UTLO & 411 \\
\hline PE & CUZCO & & & & & & & -13.52 & -71.97 & 3326 & 571 & 573 & 106 & $3 \mathrm{~K}$ & UTLO & 411 \\
\hline PE & HUANUCO & & & & & & & -9.92 & -76.23 & 1894 & 257 & 261 & 20 & $3 \mathrm{~K}$ & UTLO & 411 \\
\hline PE & ICA & & & & & & & -14.07 & -75.72 & 439 & 259 & 262 & 147 & $5 \mathrm{~K}$ & UTLO & 411 \\
\hline PE & ICA & & & & & & & -14.07 & -75.72 & 439 & 259 & 262 & 147 & $6 \mathrm{~K}$ & UTLO & 411 \\
\hline PE & LIMA & & & & & & & -12.05 & -77.05 & 32 & 7 & 41 & 333 & $9 \mathrm{~K}$ & UTLO & 411 \\
\hline PE & LIMA & & & & & & & -12.05 & -77.05 & 32 & 7 & 41 & 333 & $8 \mathrm{~K}$ & UTLO & 411 \\
\hline PE & TRUJILLO & & & & & & & -8.10 & -79.03 & 51 & 495 & 496 & 33 & $3 \mathrm{~K}$ & UTLO & 411 \\
\hline HYP & PE19795 & 1960 & 11 & 20 & 22:01:56 & -6.800 & -81.000 & & & & 55 & 6.8 & $\mathrm{M}_{\mathrm{s}} 6$ & $6 \mathrm{M}$ & & 2 \\
\hline PE & PIURA & & & & & & & -5.20 & -80.62 & 35 & 54 & 81 & 35 & $6 \mathrm{~K}$ & UTLO & 411 \\
\hline PE & PIURA & & & & & & & -5.20 & -80.62 & 35 & 54 & 81 & 35 & $5 \mathrm{~K}$ & UTLO & 411 \\
\hline
\end{tabular}


quake parameters (i.e. epicentral co-ordinates, epicentral or maximum intensity, magnitude, depth, number of related IDP - although this is not always reported); in the following lines, the IDP related to the earthquake are listed.

All intensities are given in either $\mathrm{MM}$ (Modified Mercalli) or MSK (Medvedev-Sponheuer-Karnik) macroseismic scales. The investigator who assigned the intensity value is identified as «interpreter» $(« \mathrm{DH} »$ or «UTLO» in table II). A more detailed description of the catalogue format is given in vol. 1 of CERESIS (1985), including the list of the «interpreters» and the references they used. The database contains some cases of duplicate records for the same events and/or localities. This is either due to different interpreter/source or to uncertainties in the intensity assessment. For instance, if the «interpreter» assess an $I=7 / 8$ for a given locality, two records are present in the database, one with $I=7$ and another with $I=8$.

The increased availability of historical data interpreted in terms of IDP has stimulated seismologists to develop standard and repeatable procedures to determine earthquake source parameters, in order to lower the level of subjectivity they are usually determined upon.

The Boxer program (Gasperini et al., 1999) is an example of these new procedures. The algorithm computes the parameters of the earthquake source from IDP; it provides the seismological parameters (latitude and longitude of the epicentre, moment magnitude) and a geometric model of the source through a box that represents the surface projection of the modelled seismogenic source.

The original version of the program is designed only for dip-slip faults and it was initially calibrated for Apenninic earthquakes (in most cases shallow events). The program represents each source as the surface projection of a fault dipping $45^{\circ}$ towards a direction perpendicular to the fault strike (Gasperini et al., 1999). The projection width constrains the fault at depth.

The program was largely tested in Italy (Valensise and Pantosti, 2001; Mirto et al., 2001) and Europe, first in the frame of the EC project FAUST (Faults as a Seismologist's Tool, http://faust.ingv.it), whose goal was to determine the source parameters (Leschiutta and Mirto, 2000; Stucchi et al., 2000) of some Eu- ropean earthquakes using the European Mediterranean Intensity Database (EMID), and then by other European seismologists (Kouskouna, 2002).

Given the widespread use of Boxer, we decided to test it using the CERESIS database. We are perfectly aware that in South America earthquakes are chiefly deep crustal or due to subduction processes, and the structures are often strike-slip faults. Nonetheless, we applied the Boxer method to some earthquakes of the South-American region without considering the applicability limit of Boxer to pure dip-slip faults and attenuation of earthquake intensity for the Italian territory. As such, our results represent a very preliminary attempt of determining source parameters for some large South American earthquakes.

\subsection{Examples of use: analysing records to determine sources parameters}

With the aim of determining source parameters using the macroseismic data provided by CERESIS database we focused on large events; 201 earthquakes above the threshold of $I_{0} \geq 8$, are considered in this study. Figure 2a,b shows the distribution of earthquakes and number of IDP for 50-year time windows, for the 201 selected earthquakes.

In some of the studied cases, the CERESIS database contains for an individual earthquake duplicated intensity values assessed at the same place. Since the Boxer program accepts one intensity value only for each place, an a priori choice has been made; both in case of different interpreters and of uncertain intensity, the highest intensity value has been adopted. The number of IDP in the CERESIS database for the 201 events with $I_{0} \geq 8$ is 5515, while those used in this study are 4245 only (table III).

Out of the 201 events above the threshold $\left(I_{0} \geq 8\right)$ a more detailed selection was carried out considering the characteristics of the Boxer program (table IV). Therefore only events with an appropriate number of IDP (no. $\geq 10$ ) have been considered; all the earthquakes with a focal depth $\geq 30 \mathrm{~km}$ have been disregarded as well as the offshore and subduction events. The identification of the subduction events was sup- 

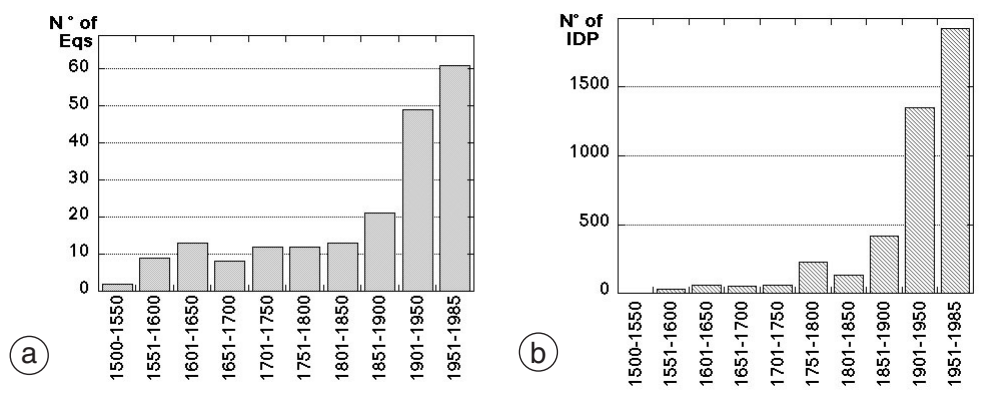

Fig. 2a,b. a) Number of earthquakes per 50-year time-windows and b) number of IDP per 50-year time-windows, for the 201 earthquakes with $I_{0} \geq 8$ from CERESIS database.

Table III. Number of records in the CERESIS database for earthquakes with $I_{0} \geq 8$.

\begin{tabular}{lcccc}
\hline \hline \multirow{2}{*}{ Country } & \multicolumn{3}{c}{ CERESIS database $I_{0} \geq 8$} & This study $I_{0} \geq 8$ \\
\hline & Time-window & No. of earthquakes & No. of IDP & No. of IDP used \\
\cline { 2 - 5 } Argentina & $1692-1985$ & 17 & 483 & 480 \\
Bolivia & $1650-1947$ & 6 & 30 & 30 \\
Brazil & 1955 & 1 & 10 & 10 \\
Chile & $1730-1976$ & 13 & 382 & 330 \\
Colombia & $1644-1981$ & 43 & 1287 & 921 \\
Ecuador & $1541-1980$ & 29 & 912 & 871 \\
Peru & $1471-1974$ & 63 & 1775 & 990 \\
Trinidad \& Tobago & 1825 & 1 & 14 & 14 \\
Venezuela & $1530-1975$ & 28 & 622 & 599 \\
\hline Total & & 201 & 5515 & 4245 \\
\hline
\end{tabular}

ported by the available literature. Dorbath et al. (1990) assessed the size of large and great historical earthquakes in zones along the trench in Peru. These zones correspond roughly to segmentation defined by the geometry of the subduction zone. Other authors, such as Lomnitz (1970), Kelleher (1972), Pennington (1981), Kanamori and McNally (1982), Nishenko (1985), Comte and Pardo (1991), Mongue (1993), Tavera and Buforn (1998), Tavera (2002) and Carpio and Tavera (2002) listed the major earthquakes along South American subduction zone. They are the 1746, 1868, 1912, 1913, 1970 earthquakes in Peru, and the 1730, 1751, 1822, 1868, 1877, 1928, 1966 earth-
Table IV. Criteria used for selecting earthquake records from 201 events with $I_{0} \geq 8$.

\begin{tabular}{lc}
\hline \multicolumn{1}{c}{ Criteria } & $\begin{array}{c}\text { No. of } \\
\text { earthquakes } \\
\text { eliminated }\end{array}$ \\
\hline Number of IDP $<10$ & 89 \\
Focal Depth $>30 \mathrm{~km}$ & 45 \\
Off Shore events & 18 \\
Subduction events & 11 \\
Incoherent IDP distribution & 1 \\
Total events eliminated & 164 \\
\hline
\end{tabular}


quakes in Chile. These are the events not considered by this study. Adopting the above described criteria only 37 events have been processed with the method proposed by Gasperini et al. (1999). In fig. 3, boxes representing the source dimension, size and location obtained from macroseismic data are shown.

Table $\mathrm{V}$ gives the CERESIS parameters, the parameters computed by Boxer and a comparison between them. In general, the moment magnitude calculated by Boxer program is smaller than the magnitude $M_{S}$ reported by CERESIS. The epicentral intensities are essentially similar. Table $\mathrm{V}$ list also « $\Delta$ Epic.» that is the distance between the CERESIS epicentres and the macroseismic ones computed by the Boxer program. This comparison between epicentres shows some cases with distance greater than $150 \mathrm{~km}$. The only justifiable difference is the one concerning 9 April 1928, Peru earthquake, because in this case CERESIS gives the instrumental localisation. For the other two events (26 March 1812 Venezuela and 27 October 1894 Argentina earthquakes) a more detailed analysis would be necessary (but it is out of the scope of this study).
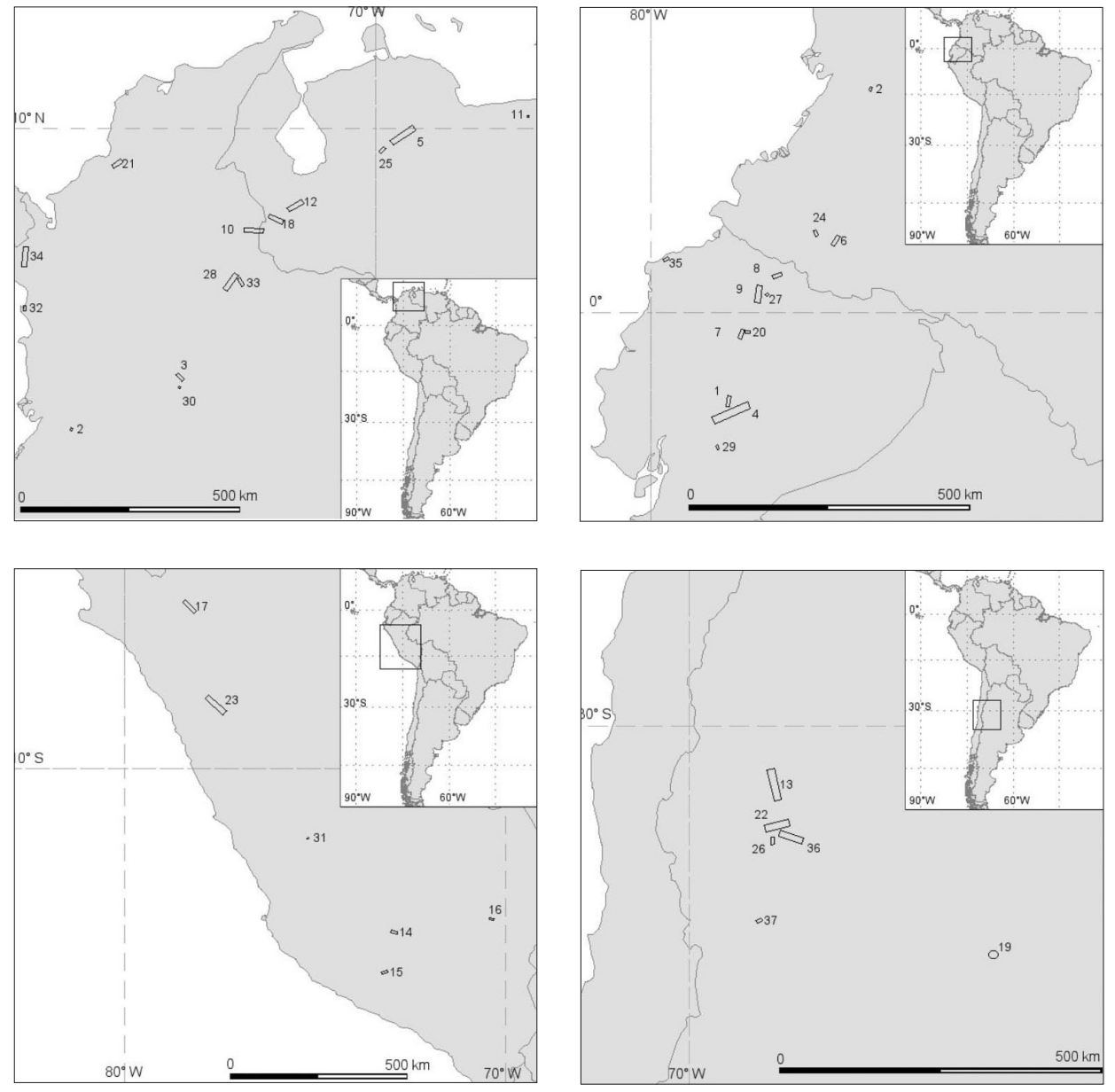

Fig. 3. Location of 37 intensity-based sources (box) quoted in table V. The adjacent number to each box corresponds to ID_Box (table first column). 


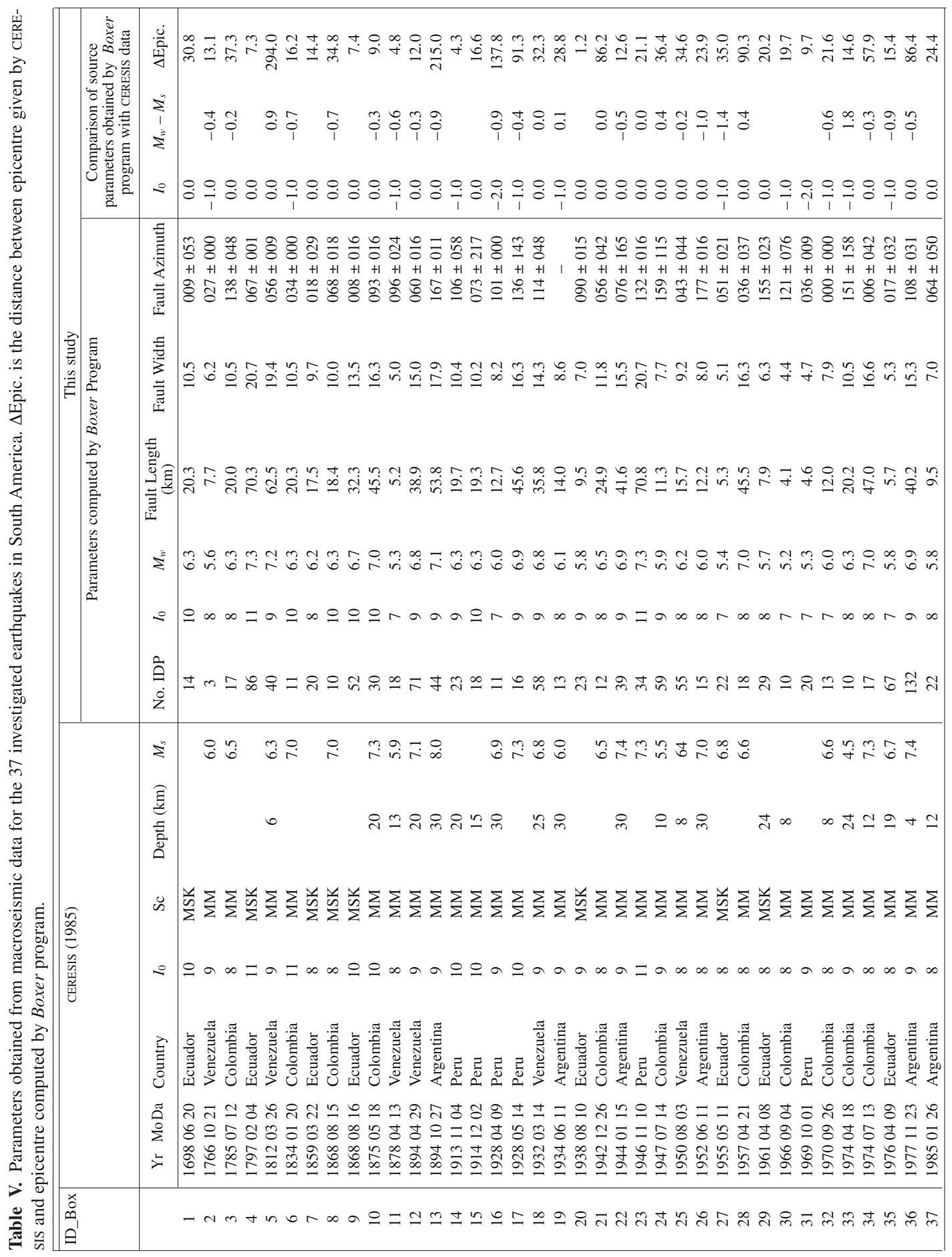




\subsection{The earthquake of 29 April 1894 in the Venezuelan Andes}

The 1894 event is one of the largest historical earthquakes in Venezuela. It is known as the Great earthquake of the Venezuelan Andes and it almost completely ruined the towns of Santa Cruz de Mo-
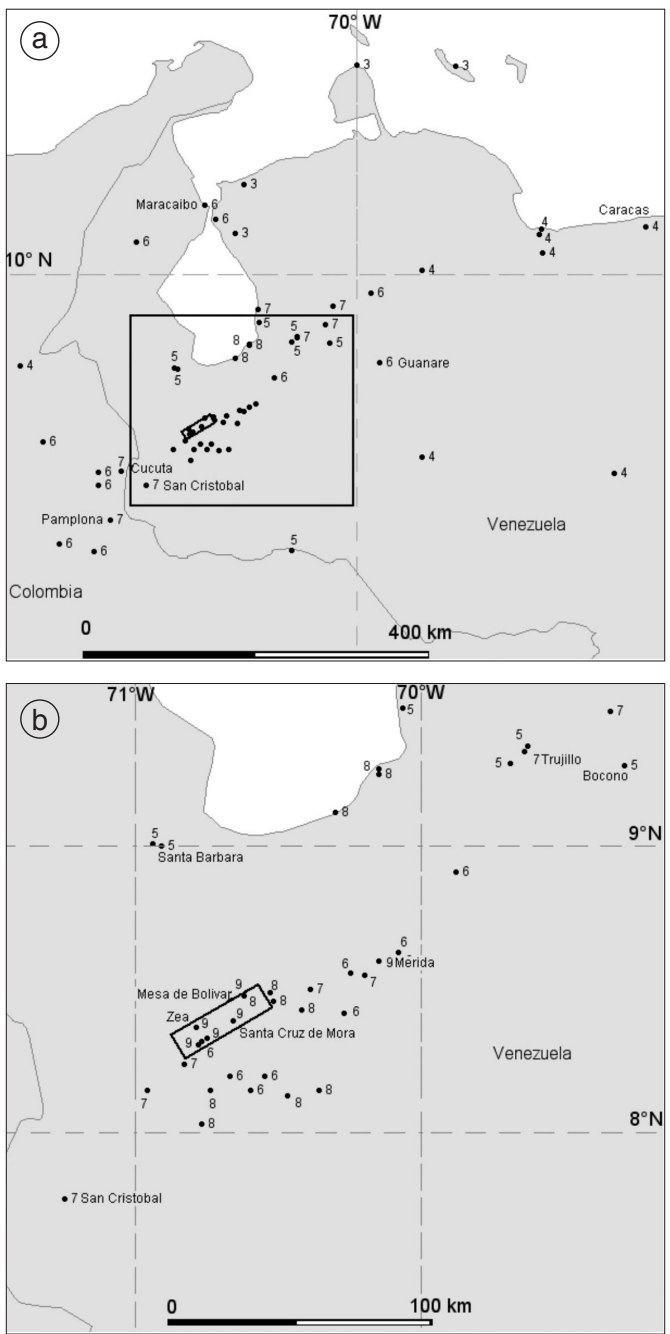

Fig. 4a,b. The 29 April 1894 earthquake in Venezuela: a) 71 intensity data points reported by CERESIS (1985); b) the box represents the source dimension, size and location obtained from intensity data following the method proposed by Gasperini et al. (1999). ra, Zea, Mesa de Bolivar, Tovar, San Juan de Lagunillas, Chiguará y Mérida (Audemard, 1998). Altuve (1998), Rengifo and Laffaille (1998) and Rivera de Uzcategui and Torres (1998) investigated and collected historical sources on this event.

CERESIS (1985) on the basis of the historical work by Grases (1979), gives the epicentre as $8.50^{\circ} \mathrm{N}, 71.70^{\circ} \mathrm{W}$, at a $20 \mathrm{~km}$ depth, magnitude $M_{s}=7.1$, and maximum reported intensity IX (MM). Also the epicentre given by Rengifo and Laffaille (1998) is similar: $8.55^{\circ} \pm 0.05^{\circ} \mathrm{N}$, $71.69^{\circ} \pm 0.05^{\circ} \mathrm{W}$, but with a focal depth estimated in $14 \pm 2 \mathrm{~km}$, and a magnitude ranging between 7.1 and 7.4. Recently this event has been directly associated to the southern section of the Bocono fault through paleoseismological investigations (Audemard, 1997, 1998; Audemard et al., 1999) and its magnitude has been estimated between $M_{s} 7.1$ and 7.3. Based on the 71 macroseismic data reported by CERESIS (fig. $4 \mathrm{a}, \mathrm{b}$ ), the macroseismic epicentre $\left(8.39^{\circ} \mathrm{N}, 71.70^{\circ} \mathrm{W}\right)$ and the moment magnitude $\left(M_{w}=6.8\right)$ were obtained through the Boxer program.

As shown in fig. 4a,b, the Boxer program suggests that the 1894 earthquake ruptured a source with a length of $39 \mathrm{~km}$ and an azimuth of $\mathrm{N} 60^{\circ} \mathrm{E}$. This result can be considered consistent with the regional tectonic trend, and it is further supported by the conclusions drawn by Audemard et al. (2000). In fact, they mention this earthquake as an event related to historical movement (sense of movement: dextral-normal) of the South of Mérida Section of Bocono fault system, in Venezuela.

\section{Conclusions}

Between 1950 and 1970, before the Ceresis foundation, compilations, studies and catalogues were produced by various seismologists and South American seismological agencies. In 1985, the earthquake catalogue and intensity database for eight South American countries (Argentina, Bolivia, Brazil, Colombia, Chile, Ecuador, Peru and Venezuela) and one Caribbean country (Trinidad and Tobago) were compiled through the SISRA Project, which were then assembled in the CERESIS earthquake catalogue and intensity database (CERESIS, 1985). Data came from previous compilations and new interpretations of his- 
torical and instrumental records within a time window of about 500 years; earthquakes occurred in pre-Hispanic times are not included, apart from some information on the 1471 earthquake in Peru. Given the huge amount of data and the level of its organisation, the South American intensity database produced by CERESIS is a paramount achievement in the framework of macroseismic studies.

A recently developed application, which processes macroseismic data (Boxer, Gasperini et al., 1999) and was originally tested in Italy and Europe, has been adopted in this study. Even though this application should be carefully tested, given the nature of the South American catalogues, which include both shallow and subduction earthquakes, the results we achieved are to some degree conformable.

To conclude, we emphasise that more efforts are needed to develop methods that make use of macroseismic intensity data to constrain the essential characteristics of the seismic sources for South America.

\section{Acknowledgements}

We are very thankful to Massimiliano Stucchi for his thoughtful suggestions and continuous encouragement. We also thank Paola Albini for reviewing the manuscript and making helpful comments. Thanks are extended to an anonymous referee whose comments improved an early version of the manuscript.

\section{REFERENCES}

AlteZ, R. and J. Grases (2004): A brief history of a restless vision: seismological research in Venezuela, Ann. Geophysics, 47 (2-3), 451-464 (this volume).

Altuve, F. (1998): El gran terremoto de los Andes venezolanos y las juntas de socorro, Rev. Geogr. Venezol. 39 (1-2), 163-178.

Anonymous (1650): Actas de Cabildo de Potosi, Archivo Nacional de Bolivia, La Paz.

Audemard, F. (1997): Holocene and historical earthquakes on the Boconó fault system, southern Venezuelan Andes: trench confirmation, J. Geodyn., 24 (1-4), 155-167.

Audemard, F. (1998): Contribución de la paleosismología a la simicidad historica: Los terremotos de 1610 y 1894 en los Andes venezolanos meridionales, Rev. Geogr. Venezol., 39 (1-2), 87-105.
Audemard, F., D. Pantosti, M. Machette, C. Costa, K. Okumura, H. Cowan, H. Diederix, C. Ferrer and ParTICIPANTS OF THE SOUTH AMERICAN FIELD WORKSHOP ON PAleoseismology (1999): Trench investigation along the Mérida section of the Boconó Fault (Central Venezuelan Andes), Venezuela, Tectonophysics, 308, 1-2, 1-21.

Audemard, F.A., M.N. Machette, J.W. Cox, R.L. Dart and K.M. HALLER (2000): Map and database of quaternary faults in Venezuela and its offshore regions. A project of the International Lithosphere Program Task Group II-2, Major Active Faults of the World, U.S. Geol. Surv., Open-File Rep. 00-018, pp. 78.

Ballivian, M.V. (1909): Datos sobre terremotos y temblores habidos en territorio Boliviano. Recopilación de varios autores, 1a serie, Bol. Of. Nac. Estadística.

BARRIGA, V. (Editor) (1951): Los Terremotos en Arequipa, 1582-1868, Documentos de los Archivos de Arequipa y de Sevilla, Arequipa, pp. 426

Berrocal, J., M. Assumpcao, R. Antezana, C. Dias Neto, R. Ortega, J. Franca and J. Velosos (1984): Sismicidade do Brasil, IAG-USP, pp. 320.

Boussingault, J.B. and F. Roulin (1849): Viajes científicos a los Andes Ecuatoriales, Colección de Memorias sobre Física, Química e Historia Natural de la Nueva Granada, Ecuador y Venezuela, traducidas por J. AcosTA y precedidas de algunas nociones de geología por el mismo (Librería Castellana, Laserre, Paris), pp. 322.

CAPANEMA, G. (1859): Quais as tradições ou vestígios geológicos que nos levem a certeza de ter havido terremotos no Brasil, Rev. Inst. Hist. Geogr. Bras., 22, 135-159.

CARPIO, J. and H. TAVERA (2002): Estructura de un catálogo de tsunamis para el Perú basado en el catálogo de Gusiakov, Bol. Soc. Geol. Perú, 94, 45-59.

CERESIS, Centro Regional de Sismología para América del Sur (1985): Earthquake Mitigation Program in the Andean Region (Project SISRA), CERESIS, Perú, 14 vols.

CoMte, D. and M. PARdo (1991): Reappraisal of great historical earthquakes in the northern Chile and southern Peru seismic gaps, Nat. Hazards, 4, 23-44.

Descotes, P.M. and R. CABre (1973): Historia Sísmica de Bolivia, Rev. Geofís. Panam., 2 (1), 251-781.

Dorbath, L., A. Cisternas and C. Dorbath (1990): Assessment of the size of large and great historical earthquakes in Peru, Bull. Seismol. Soc. Am., 80 (30), 551-576.

EGRED, J. (1968): Breve historia sísmica de la República del Ecuador (1534-1965), Bol. Bibl. Geofís. Oceanogr. Am., México, 4.

EMID, Euro-Mediterranean Intensity Database (on line: http://emidius.mi.ingv.it/EMID/).

EsPejo, G. (1974): Catálogo de Sísmos Fuertes en el Perú (Instituto Geofísico del Perú, Servicio Sismológico, Lima).

Espinosa Baquero, A., A.A. Gómez Capera and E. SALCEDO HuRTADO (2004): State-of-the-art of the historical seismology in Colombia, Ann. Geophysics, 47 (2-3), 437-449 (this volume).

FAUST: Faults as a Seismologist's Tool (on line: http://FAUST.ingv.it).

Gasperini, P., F. Bernardini, G. Valensise and E. Boschi (1999): Defining seismogenic sources from historical felt reports, Bull. Seismol. Soc. Am., 89, 94-110.

Grases, G.J. (1979): Investigación sobre los Sismos Detructores que Hayan Afectado el Oriente de Venezuela, 
delta del Orinoco y Regiones Adyacentes (Proyecto Instituto Tecnológico Venezolano del Petroleo), 2 vols.

Greve, F. (1964): Historia de la sismología en Chile, Publicación Instituto de Geofísica y Sismología, Santiago de Chile, pp. 94.

GRUNTHAL, G. (Editor) (1998): European macroseismic scale 1998, Cah. Cent. Eur. Géodyn. Séismol., Luxembourg, 15.

HARRINGTON, H.J. (1944): Volcanes y Terremotos (Editorial Pleamar, serie Biblioteca Conocimiento, Buenos Aires, Argentina).

Huaco, D. (1983): Catálogo Sísmico del Perú (Proyecto SISRA, Instituto Geofísico del Perú, Lima).

KanAmori, H. and K.C. MCNALly (1982): Variable rupture mode on the subduction zone along the Ecuador, Bull. Seismol. Soc. Am., 72, 1241-1253.

Kausel, E. (1979a): Comportamientos de diferentes suelos durante el terremoto del 16 de agosto de 1906, Inf. Comisión Chilena Energía Nuclear, pp. 9 and appendix.

Kausel, E. (1979b): Los Terremotos de Agosto 1868 y Mayo 1977, que Afectaron al sur del Perú y Norte de Chile (Departamento de Geofísica, Santiago de Chile, Inédito).

KelleHER, J. (1972): Rupture zones of large South American earthquakes and some predictions, J. Geophys. Res., 77 (11), 2087-2103.

KousKounA, V. (2002): Characteristic fault directions and rapture zones obtained from historical and instrumental earthquakes from the gulf of Corinth, in XXVIII ESC General Assembly, SCA-1, Genoa, 1-6 September 2002, p. 137 (abstract).

La Estrella de Oriente (1890), Newspaper, Santa Cruz, Bolivia.

La Industria (1884), Newspaper, Sucre, Bolivia.

LARA, M.S. (1860): Crónicas anónimas, Archivos Universidad de Santa Cruz, Santa Cruz, Bolivia.

LeschiUtTA, I. and C. MiRTo (2000): Using historical earthquake data for the determination of the source parameters of some European earthquakes, in Proceedings of the ESC WG Historical Seismology Workshop, 1-5 September, Macerata (Italy), 54-59.

Libros de Cabildo de la Ciudad de Quito (1645): Manuscritos originales de las Actas de Cabildo de la Ciudad de Quito, a partir de su fundación, Archivo Histórico Municipal Quito.

Libros de Cabildo de la Ciudad de Quito (1675): Manuscritos originales de las Actas de Cabildo de la Ciudad de Quito, a partir de su fundación, Archivo Histórico Municipal Quito.

Libros de Cabildo de la Ciudad de Quito (1775): Manuscritos originales de las Actas de Cabildo de la Ciudad de Quito, a partir de su fundación, Archivo Histórico Municipal Quito.

LomNITZ, C. (1970): Major earthquakes and tsunamis in Chile during the period 1575 to 1955 , Geol. Rundsch., Bd. 59, Heft 3, 938-960.

LUNKENHEIMER, F. (1930): El terremoto del Sud-Mendocino del 30 de Mayo de 1929 (Observatorio Astronómico, Universidad de la Plata, La Plata, Argentina).

Mirto, C., E. Ercolani, I. Leschiutta, F. Mosciatti and G. Rubbia Rinaldi (2001): I database macrosismici on-line dei terremoti italiani ed europei e il loro uti- lizzo per la determinazione dei parametri di sorgente dei terremoti, in Atti del VI Workshop GIAST, 14-16 Settembre 1999, Sansepolcro, Arezzo, Italy, 77-89.

Mongue, J. (1993): Estudios de Riesgo de Tsunami en Costas Chilenas, in Jornadas Chilenas de Sismología en Ingeniería Antisísmica, Santiago de Chile, 2, 3-22.

Montessus de Ballore, F. (1911): Historia Sísmica de los Andes Meridionales (Imprenta Universitaria, Santiago de Chile), pp. 345.

Montessus de Ballore, F. (1912): Bibliografía General de Temblores y Terremotos (Sociedad Chilena de Historia y Geografía, Santiago de Chile).

Montessus de BAllore, F. (1916): Historia sísmica de los Andes Meridionales (Editorial Cervantes, Santiago de Chile).

Nishenko, S. (1985): Seismic potential for large and great interplate earthquakes along the Chilean and southern Peruvian margins of South America: a quantitative reappraisal, J. Geophys. Res., 90 (B5), 3589-3615.

OBSERVATORIO ASTRONOMICO DE QUITO (1959): Breve historia de los principales terremotos en el Ecuador, Publicación del Comité del Año Geofísico Internacional del Ecuador, Quito, pp. 35.

Ocola, L. (1984): Catálogo sísmico del Perú, Proyecto SISAN, Instituto Geofísico del Perú, Lima, pp. 464.

Olsacher, J. (1935): Terremoto de Sanpacho (Provincia de Córdoba), 10 y 11 de junio de 1934, Rev. Mus. Prov. Cienc. Nat., 1, p. 52.

Pennington, W.D. (1981): La subducción de la cuenca oriental de Panamá y la sismotectónica del noroeste de Sur America, Investigaciones Geofísicas sobre las Estructuras Océano-Continentales del Occidente Colombiano (Instituto Geofísico, Universidad Javeriana, Bogotá), 97-137.

Polo, J.T. (1904): Sipnosis de los Terremotos y Volcanes de Perú (Sociedad Geográfica de Lima), vols. VII-XVI.

RENGIFO, M. and J. LAFFAILLE (1998): El terremoto del año 1894 en los Andes venezolanos, Rev. Geogr. Venez., 39 (1-2), 141-161.

Rivera DE Uzcategui, A. and R. Torres (1998): Estudio de daños originados a las iglesias de la ciudad de Mérida por la acción de los terremotos de 1812 y 1894, Rev. Geogr. Venez., 39 (1-2), 219-256.

RubBiA, G. (2004): A review of intensity data banks online, Ann. Geophysics, 47 (2-3), 873-884 (this volume).

Silgado, E. (1968): Historia de los sismos más notables ocurridos en Perú (1515-1960), Bol. Bibl. Geogr. Oceanogr. Am., 4, 191-241.

SIlGado, E. (1978): Historia de los sismos más notables ocurridos en el Perú (1513-1974), Instituto Geología y Minería, Lima, Boletín No. 3, pp. 130.

SILGADO, E. (1985): Destructive earthquakes of South America 1530-1894, in Earthquake Mitigation Program in the Andean Region (Project SISRA, CERESIS, Lima), 10, pp. 328.

SILGADO, E. (1992): Investigación de Sismicidad Histórica en la América del Sur en los Siglos XVI, XVII, XVIII y XIX (Concytec/CEREsis, Perú), pp. 108.

Stucchi, M., I. Leschiutta and C. Mirto (2000): On the influence of the uncertainties of historical data on the determination of earthquake parameters, in XXVII ESC General Assembly, WSA-1, 10-17 September 2000, 
Lisboa, pp. 115 (abstract)

TAVERA, H. and E. BUFORN (1998): Sismicidad y sismotectónica de Perú, in Física de la Tierra, edited by E. BUFORN and A. UDIAS (Servicio de Publicaciones Universidad de Complutense), 10, 187-219.

Tavera, H. (2002): Historia de un Terremoto Anunciado para la Región sur del Perú (Centro Nacional de Datos Geofísicos, Instituto Geofísico del Perú), 11-18.

VAlensise, G. and D. PANTosti (Editors) (2001): Database of potential sources for earthquakes larger than $M 5.5$ in Italy, Ann. Geofis., 44 (suppl. to no. 4), pp. 180, with CD-ROM.

VeGA, B.A. (1978): Catálogo sísmico de Bolivia (Proyecto SISAN-OEA, Observatorio San Calixto, La Paz).

VoGT, J. (2004): A glimpse at the historical seismology of the West Indies, Ann. Geophysics, 47 (2-3), 465-476 (this volume).

VolPONI, F. (1962): Aspectos sismólogicos del Territorio Argentino, in Actas Primeras Jornadas Argentinas de ingeniería Antisísmica, Buenos Aires. 